\title{
The autocrine effect of activin A on human ovarian clear cell adenocarcinoma cells
}

\author{
YASUSHI MABUCHI ${ }^{1}$, MAREO YAMOTO ${ }^{2}$, SAWAKO MINAMI $^{1}$ and NAOHIKO UMESAKI ${ }^{1}$ \\ ${ }^{1}$ Department of Obstetrics and Gynecology, Wakayama Medical University, School of Medicine, \\ 811-1 Kimiidera, Wakayama 641-0012; ${ }^{2}$ Department of Obstetrics and Gynecology, Wakayama Rosai Hospital, \\ Japan Labour Health and Welfare Organization, 435 Koya Wakayama 640-8435, Japan
}

Received January 11, 2006; Accepted March 28, 2006

\begin{abstract}
The functions of activin, a member of TGF- $\beta$ superfamily, in ovarian clear cell adenocarcinoma remain unsolved, although we recently found that inhibin BA-subunit, activin A, activin receptor type IA, type IB, type IIA, type IIB, Smad2, Smad3 and Smad4 were localized in tumor cells of the ovarian clear cell adenocarcinoma tissue by immunohistochemistry. In the present study, in order to investigate the role of activin concerning cell growth in ovarian clear cell adenocarcinoma cells, we determined the production of activin $\mathrm{A}$ and inhibin $\mathrm{A}$, and the expression of activin receptors and Smads using the human ovarian clear cell adenocarcinoma cell line JHOC-5. Moreover, we examined the effects of activin $\mathrm{A}$ on the activation of activin signaling pathway and on the proliferation in JHOC- 5 cells. We detected a measurable amount of activin A in the culture medium of JHOC-5 cells, although inhibin A was not detected. The expression of activin receptor type IA, IB, IIA, IIB, Smad2, Smad3 and Smad4 was observed in JHOC-5 cells. Activin A induced a significant increase in proliferation of JHOC-5 cells compared with the untreated control. On the other hand, activin A did not affect the growth of JHOC-5 cells and no statistically significant difference was observed in the presence of follistatin which is a specific binding protein of activin. Phosphorylated Smad2, an activated form of Smad2, was detected both in treated JHOC-5 cells and in untreated cells by activin A. Activin A significantly increased the expression of phosphorylated Smad2 in JHOC-5 cells. Therefore, it is possible that activin has autocrine roles in tumor growth of ovarian clear cell adenocarcinoma cells.
\end{abstract}

Correspondence to: Dr Yasushi Mabuchi, Department of Obstetrics and Gynecology, Wakayama Medical University, School of Medicine, 811-1 Kimiidera, Wakayama 641-0012, Japan

E-mail: booyan@wakayama-med.ac.jp

Key words: ovarian cancer, clear cell adenocarcinoma, activin, inhibin, activin receptor, Smad, phosphorylated Smad, cell growth

\section{Introduction}

Ovarian cancer is the leading cause of death due to gynecological malignancy, even though the diagnostic methods or treatment techniques for cancers have progressed markedly. Ovarian cancer has special factors of its own that are influential in the poor prognosis, such as difficulty of early detection and resistance to chemotherapy. Clear cell adenocarcinoma of the ovary has one of the poorest prognosis of all the histological types of ovarian cancer. The percentage of patients with stage I is significantly higher in patients with clear cell adenocarcinoma than in those with serous adenocarcinoma (1). However, clear cell adenocarcinoma has a poorer prognosis than serous carcinoma (2), and the response rate to platinum-based chemotherapy in patients with clear cell adenocarcinoma is significantly lower than that in patients with serous adenocarcinoma (1). The doubling time for clear cell adenocarcinoma cells is significantly longer than that for serous adenocarcinoma cells (3). Clinically, several characteristics distinguish clear cell adenocarcinoma from the other histological types of epithelial ovarian carcinoma, including high frequency of associated endometriosis, resistance to chemotherapy and poor prognosis even in early stage of disease.

Activins and inhibins belong to the transforming growth factor (TGF)- $B$ superfamily (4) and are involved in the regulation of cell growth and differentiation in various kinds of tissues $(5,6)$. Activins and inhibins are dimeric glycoproteins which were isolated from ovarian follicular fluid. Activins are composed of two homologous $B$-subunits, and three forms, activin $A(\beta A / B A)$, activin $B(\beta B / \beta B)$, and activin $A B(\beta A / \beta B)$, have been identified. Inhibins consist of an $\alpha$-subunit that is linked to a $\beta$-subunit by disulfides, and two forms, inhibin A $(\alpha / \beta A)$ and inhibin $B(\alpha / \beta B)$, have been characterized (7). Activins stimulate the secretion of follicle-stimulating hormone (FSH) from anterior pituitary gland, whereas inhibins inhibit FSH secretion.

Activin and TGF- $\beta$ ligands bind to ligand-specific receptors, yet the actions of both growth factors are mediated through the same cytoplasmic signaling components, Smads (8-11). Activin initially binds to an activin type II receptor (ActR IIA or ActR IIB) with high affinity and specificity. Following the 
binding, the complex recruits a second (type I) receptor (ActR IA or ActR IB) to form an activin type I-II receptor complex. This union promotes phosphorylation at serine or threonine of type I receptors which results in the phosphorylation of two possible receptor-regulated cytoplasmic coactivators (R-Smad 2 and R-Smad 3), which then interact with the common Smad (co-Smad 4) (12-15). The phosphorylated and activated Smad 2/4 or Smad 3/4 complex translocates to the cell nucleus where they play a prominent role of transcription of activin or TGF- $\beta$ responsive genes (14). Inhibitory Smads (I-Smad 6 and I-Smad 7) block the phosphorylation of R-Smads by preventing their association with the type I receptor in the cell cytoplasm, which results in the inhibition of additional Smad signaling $(14,16)$.

The signaling pathway of inhibin is less clearly understood. No specific receptor has been isolated nor specific threonine/ serine kinases identified from genomic searches (17). Lewis et al (18) reported that the association of inhibin with an accessory binding protein (betaglycan, the so-called TGF- $\beta$ receptor type III) promoted inhibin binding to ActR II and that the association was a very potent antagonist of activin binding and action.

We previously reported that sex cord stromal tumor might produce inhibin A and inhibin B (19). Concerning the epithelial tumors, we also reported that inhibin and activin might be secreted by the mucinous adenoma and the cystic tumor with borderline malignancy and that activins might be secreted by the mucinous adenocarcinoma and serous tumors including benign adenoma, cystic tumors with borderline malignancy, and adenocarcinoma (20). Additionally, we have reported, based on immunohistochemistry, using human materials operatively resected, that the immunostaining with antibodies against the BA-subunit, activin A, activin receptor type IA, type IB, type IIA, type IIB, Smad2, Smad3 and Smad4, not against the $\alpha$-subunit, has been observed in tumor cells of the ovarian clear cell adenocarcinoma (21). We have also suggested that activin $\mathrm{A}$, not inhibins, might have been produced by ovarian clear cell adenocarcinoma and activin signal transduction system might have existed in ovarian clear cell adenocarcinoma (21).

Based on the above reports, we hypothesized that activin might be secreted by ovarian clear cell adenocarcinoma and that activin contributed to the proliferation of clear cell adenocarcinoma via activation of its signaling pathway. In the present study, in order to investigate the autocrine role of activin concerning the cell growth in ovarian clear cell adenocarcinoma, we examined the effects of activin $\mathrm{A}$ on the activation of activin signaling pathway and on the cell proliferation using the human ovarian clear cell adenocarcinoma cell line JHOC-5.

\section{Materials and methods}

Cell line and cell culture. The ovarian clear cell adenocarcinoma cell line JHOC-5 (22) was obtained from Riken BRC Cell Bank (Tsukuba, Japan). Cells were cultured in OPTI-MEM (Gibco-BRL, Gaithersburg, MD) containing $5 \%$ fetal calf serum (FCS) (Equitech Bio Inc., Ingram, TX), penicillin $(100 \mathrm{U} / \mathrm{ml})(\mathrm{Gibco}-\mathrm{BRL})$ and streptomycin $(100 \mu \mathrm{g} /$ ml) (Gibco-BRL).
Activin A and inhibin A ELISA. JHOC-5 cells were cultured in OPTI-MEM supplemented with 5\% FCS for $48 \mathrm{~h}$. Then, the cells were carefully washed with phosphate buffered saline and they were cultured in the medium containing $2 \%$ FCS for further $48 \mathrm{~h}$. Finally, culture medium was harvested for enzyme-linked immunosorbent assay (ELISA) analysis.

Two-site ELISA kits for activin A and inhibin A were purchased from Serotec (Oxford, UK) and Diagnostic Systems Laboratories, Inc. (Webster, TX), respectively. The assays for activin A and inhibin A were two-site ELISAs based on the use of plates coated with specific monoclonal antibody against a synthetic peptide that correspond to amino acids 82-114 of the $\beta A$-subunit. The Fab fraction of mouse monoclonal antibodies against the synthetic peptide that correspond to amino acids 1-32 of the $B$-subunit or 82-114 of the BA-subunit conjugated to alkaline phosphatase was used for detection in the assays. Assays were carried out according to the protocol indicated by the manufacturer $(23,24)$. Coefficients of variations were $<7 \%$ within plates and $<9 \%$ between plates for both assays. Before assay, all the samples were heated to $100^{\circ} \mathrm{C}$ in the presence of $6 \%$ sodium dodecyl sulfate. The assay sensitivity for activin A and inhibin A was 78 and $0.3 \mathrm{pg} / \mathrm{ml}$, respectively.

Flow cytometry. The cells were detached from culture dishes by $3 \mathrm{mM}$ ethylenediaminetetracetic acid (EDTA) in PBS (phosphate buffered saline). Cells were incubated with an excess dose of mouse monoclonal antibodies against activin receptors type IA, type IIB and the goat polyclonal antibodies against activin receptors type IB, type IIA which were purchased from R\&D Systems (Minneapolis, MN) for $20 \mathrm{~min}$ at $4^{\circ} \mathrm{C}$. Cells were incubated with an excess dose of rabbit polyclonal antibodies against Smad2 and Smad3 (Zymed Laboratories, San Francisco, CA), and the mouse monoclonal antibody against Smad4 (SantaCruz Biotechnology, Santa Cruz, CA) for $30 \mathrm{~min}$ at room temperature. For negative controls, mouse IgG, goat IgG and rabbit IgG was used as the primary antibody. Cells were pretreated with $4 \%$ paraformaldehyde for fixation and with permeabilization for detecting Smad2, Smad3 and Smad4. They were then washed twice with washing buffer (PBS, $2 \%$ fetal calf serum, $0.1 \% \mathrm{NaN}_{3}$ ). After incubation with primary antibodies, samples were incubated with phycoerythrin-conjugated goat anti-mouse IgG antibody (Immunotech, Marseille, France), phycoerythrin-conjugated goat anti-rabbit IgG antibody or phycoerythrin-conjugated rabbit anti-goat IgG antibody (Sigma, St. Louis, MO). Incubation with each secondary antibody was for $20 \mathrm{~min}$ at $4^{\circ} \mathrm{C}$ when detecting activin receptors, or for $30 \mathrm{~min}$ at room temperature when detecting Smads. They were then washed twice with washing buffer. Samples were analyzed with FACSCalibur ${ }^{\mathrm{TM}}$ and data were analyzed with CellQuest software (both: Becton Dickinson, Franklin Lakes, NJ).

Western analysis. To study the effects of activin A on phosphorylated Smad 2 expression, JHOC-5 cells were cultured in the medium containing $0.2 \% \mathrm{FCS}$, and then, 10 or $30 \mathrm{ng} / \mathrm{ml}$ activin A was added to the medium after a 24-h culture. Cells were further incubated and the incubation was stopped at 30 and $60 \mathrm{~min}$ to be harvested for protein extraction. 

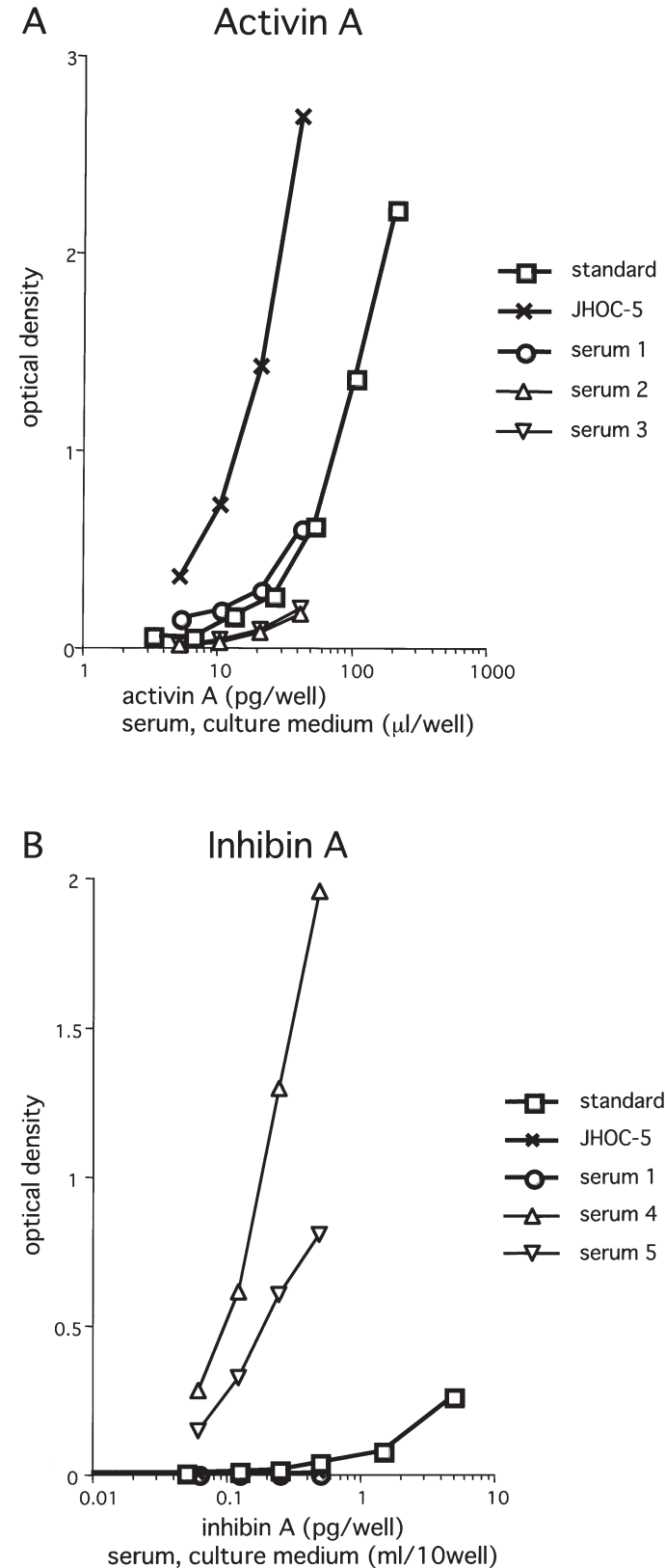

Figure 1. Measurement of activin A and inhibin A in the culture media of JHOC-5 cells and the serum of various patients. (A) Dose-response curves for the human activin A standard alongside serially diluted culture media of JHOC- 5 cells and the serum of various patients. Values are means of duplicate determinations. JHOC-5, culture media of JHOC-5 cells; Serum 1, serum of the postmenopausal patient with ovarian clear cell adenocarcinoma; serum 2 and 3 , serum of the postmenopausal patients who underwent operations due to prolapsus uteri. (B) Dose-response curves for the human inhibin A standard alongside serially diluted culture media of JHOC-5 cells and the serum of various patients. Values are means of duplicate determinations. Serum 4 and 5 , serum of the patient with hydatidiform mole and with ovarian granulosa cell tumor, respectively, as positive controls

JHOC-5 cells treated with activin A for detecting phosphorylated Smad2 and untreated cells for detecting Smad2 and Smad3 were washed 3 times with ice-cold PBS and dissolved in lysis buffer (50 mM Tri-HCl, pH 7.4, $150 \mathrm{mM}$ $\mathrm{NaCl}, 1 \mathrm{mM}$ ethyleneglycotetraacetic acid (EGTA), $1 \%$ Nonidet P-40, $0.25 \%$ sodium deoxycholate, $1 \mathrm{mM} \mathrm{Na}_{3} \mathrm{VO}_{4}$, $1 \mathrm{mM} \mathrm{NaF}$, protease inhibitor mix) by incubating for $30 \mathrm{~min}$ at $4^{\circ} \mathrm{C}$. Following centrifuging for $5 \mathrm{~min}$ at $13000 \mathrm{~g}$, the solubilized supernatants were separated by sodium dodecyl sulfate polyacrylamide gel electrophoresis (SDS-PAGE) in the presence of $1 \%$ B-mercaptoethanol, using $12.5 \%$ gels. Proteins were transferred to polyvinylidene difluoride (PVDF) membrane. Rabbit polyclonal anti-Smad2 and anti-Smad3 antibodies and rabbit polyclonal anti-phospho-Smad2 (Zymed Laboratories) antibody were used to detect protein expression with the Supersignal westdura extended duration system (Pierce, Rockford, IL). Densitometry analysis was done using CS analyzer (ATTO, Tokyo, Japan) and signals were normalized to the $B$-actin levels. All the experiments were performed 3 times to verify the results and the data were the mean of each result.

Cell proliferation assay. Cells were seeded into 96-well plate at $3 \times 10^{3}$ per $100 \mu \mathrm{l}$ in the medium with $5 \%$ FCS. After $12 \mathrm{~h}$, cells were incubated in the medium with $0.2 \%$ FCS for further $24 \mathrm{~h}$, and then, activin A $(0.1,0.3,1,3,10$ and $30 \mathrm{ng} /$ $\mathrm{ml}$ ) was added to the plates. In order to determine whether the effect of activin A was modulated by follistatin which is a specific binding protein of activin, JHOC-5 cells were stimulated by activin A also in the presence of follistatin $(100 \mathrm{ng} / \mathrm{ml})$. Cells were allowed to grow for $48 \mathrm{~h}$ and the number of viable cells was evaluated with the non-RI colorimetric cell counting kit (Dojindo Laboratories, Kumamoto, Japan). The number of viable cells was calculated and expressed as the ratio compared with the mean number of viable untreated cells. All the experiments were performed 4 times to verify the results. Data are represented as the mean \pm standard error.

Statistical analysis. All values are expressed as the means \pm standard error. Student's t-test and one way ANOVA were used to assess differences between treated group and untreated control samples. $\mathrm{p}<0.05$ were considered statistically significant.

\section{Results}

Ovarian clear cell adenocarcinoma cells secrete activin A in the culture medium. Activin A concentrations in the culture medium of JHOC-5 and in the serum of the patient with ovarian clear cell adenocarcinoma are shown in Fig. 1. Serial dilution of the culture medium of JHOC-5 and the serum of a menopausal patient with ovarian clear cell adenocarcinoma gave response curves which were parallel to those for the human activin $\mathrm{A}$ standard (Fig. 1A). The activin A concentration in the serum of the postmenopausal patient with ovarian clear cell adenocarcinoma was $1.273 \mathrm{ng} / \mathrm{ml}$ (serum 1), which was elevated compared with the postmenopausal controls, serum $2(0.434 \mathrm{ng} / \mathrm{ml})$ and serum 3 $(0.509 \mathrm{ng} / \mathrm{ml})$ (Fig. 1A). On the other hand, immunoreactive inhibin A was not detected in the culture medium of JHOC-5 or the serum of the patient with ovarian clear cell adenocarcinoma (Fig. 1B).

Ovarian clear cell adenocarcinoma cells express activin receptors and Smads. Fig. 2 displays the results of flow cytometry determination of activin receptors in the ovarian clear cell adenocarcinoma cell line, JHOC-5. We observed the 

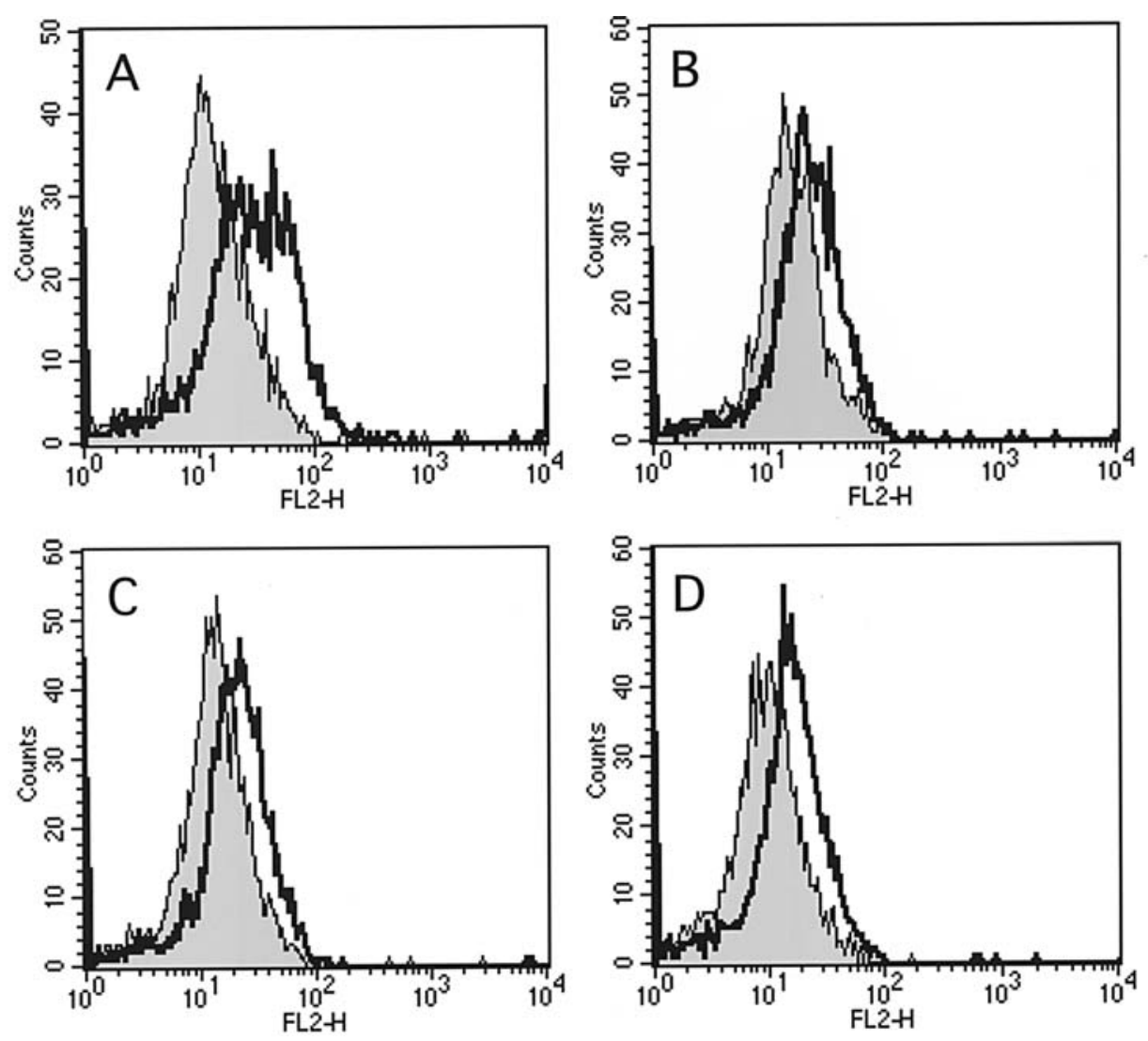

Figure 2. Flow cytometric analysis of activin receptor expression in the human ovarian clear cell adenocarcinoma cell line JHOC-5. The curve on the left of each panel represents the fluorescence of the negative control. The curve on the right of each panel represents the fluorescence of anti-activin receptor type IA (A), IB (B), IIA (C) and IIB (D).
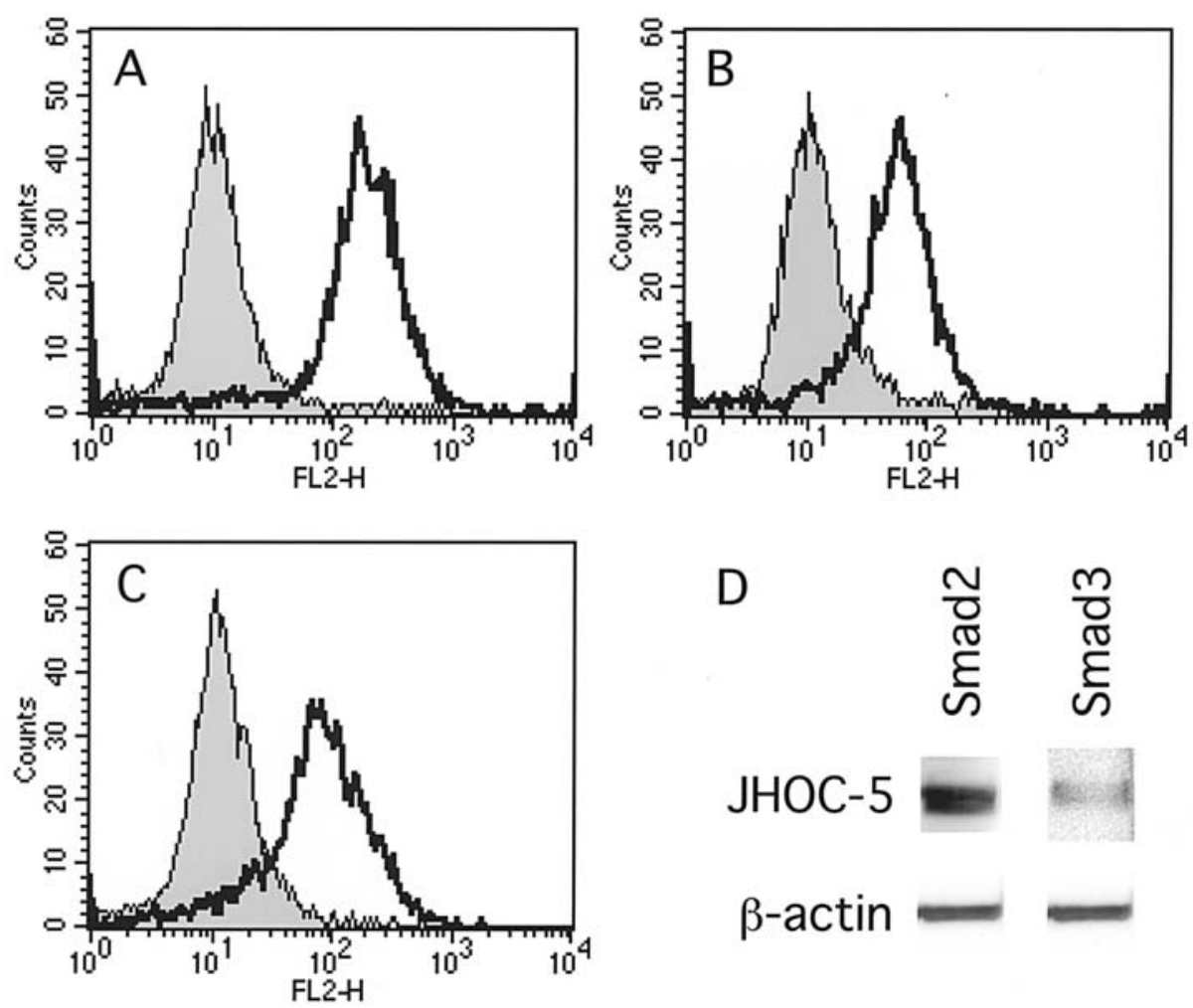

D

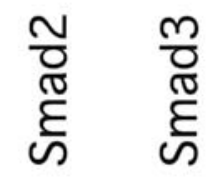

JHOC-5

$\beta$-actin

Figure 3. Flow cytometric and Western blot analysis of Smad expression in the human ovarian clear cell adenocarcinoma cell line, JHOC-5. The curve on the left of each panel represents the fluorescence of the negative control. The curve on the right of each panel represents the fluorescence of Smad2 (A), Smad3 (B) and Smad4 (C). Smad2 and Smad3 were detected in JHOC-5 cells by Western blot analysis and the B-actin levels are shown in the bottom panels (D). 


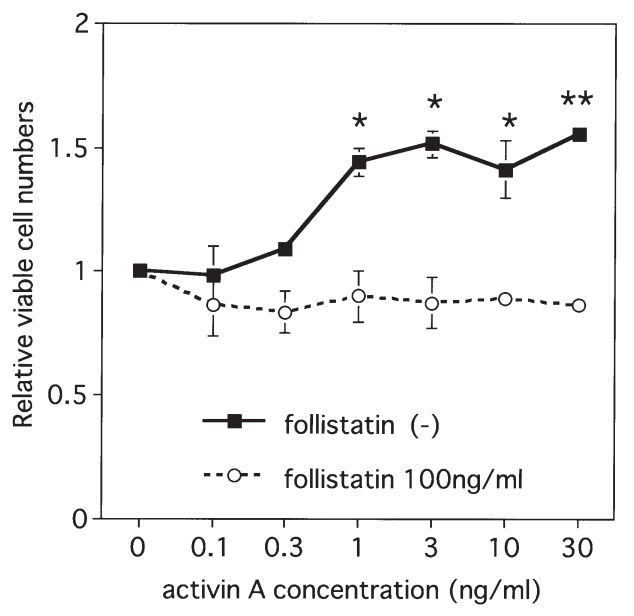

Figure 4. Effects of activin A and follistatin on JHOC-5 cell proliferation. JHOC-5 cells were cultured with various concentrations of activin A $(0,0.1$, $0.3,1,3,10,30 \mathrm{ng} / \mathrm{ml})$ with and without follistatin $(100 \mathrm{ng} / \mathrm{ml})$, and the cell viability was monitored by the non-RI colorimetric cell counting kit. Data are represented as mean \pm standard error. ${ }^{*} \mathrm{p}<0.001$ and ${ }^{* *} \mathrm{p}<0.0001$ versus the control group by ANOVA $(n=4)$.

expression of activin receptor type IA (Fig. 2A), IB (Fig. 2B), IIA (Fig. 2C) and IIB (Fig. 2D).

Fig. 3 displays the results of flow cytometry determination of Smads in the JHOC-5 cells. We observed the expression of Smad2 (Fig. 3A), Smad3 (Fig. 3B) and Smad4 (Fig. 3C). Western analysis was used to confirm the flow cytometry results. The expression of Smad2 and Smad3 was observed in the JHOC-5 cells (Fig. 3D).

Activin A increases proliferation of ovarian clear cell adenocarcinoma cells. In order to assess the effects of activin A on ovarian clear cell adenocarcinoma cells, JHOC-5 cells were examined for proliferation in response to activin A. As shown in Fig. 4, activin A (1, 3, 10 and $30 \mathrm{ng} / \mathrm{ml})$ induced a significant increase in proliferation of JHOC-5 cells compared with the untreated control $(\mathrm{p}<0.001$ with 1,3 and $10 \mathrm{ng} / \mathrm{ml}$ activin $\mathrm{A}$, and $\mathrm{p}<0.0001$ with $30 \mathrm{ng} / \mathrm{ml}$ activin $\mathrm{A}$ ). The maximal increase which was $155 \%$ of the control was observed with $30 \mathrm{ng} / \mathrm{ml}$ of activin A. On the other hand, activin A did not affect the growth of JHOC-5 cells and no statistically significant difference was observed in the presence of follistatin which is a specific binding protein of activin.

Activin A accelerates phosphorylation of Smad2 in ovarian clear cell adenocarcinoma cells. In order to investigate whether activin A stimulation activated its signaling pathway, we examined the change of the expression levels of phosphorylated Smad2, which is an activated form of Smad2, in response to activn $\mathrm{A}$.

As shown in Fig. 5, in JHOC-5 cells, phosphorylated Smad2 was detected both in treated cells and in untreated cells by activin A (Fig. 5A and B). Moreover, activin A significantly increased the expression of phosphorylated Smad2 to $132 \%$ of control at $30 \mathrm{~min}$ using $10 \mathrm{ng} / \mathrm{ml}(\mathrm{p}<0.05)$, to $198 \%$ of control at $30 \mathrm{~min}$ using $30 \mathrm{ng} / \mathrm{ml}(\mathrm{p}<0.01)$ and to $160 \%$ of control at $60 \mathrm{~min}$ using $30 \mathrm{ng} / \mathrm{ml}(\mathrm{p}<0.05)$ (Fig. 5C). The greater effects were observed in the cells treated with $30 \mathrm{ng} /$ $\mathrm{ml}$ activin A than in those treated with $10 \mathrm{ng} / \mathrm{ml}$, and the maximal effects were observed at $30 \mathrm{~min}$ in the cells treated with activin A of each concentration (Fig. 5C).

\section{Discussion}

In the present study, a measurable amount of activin A was detected, by ELISA, in the culture medium of ovarian clear cell adenocarcinoma cell line JHOC-5, although inhibin A was not detected. The present data also showed that the activin A concentration in the serum of the postmenopausal patient
A

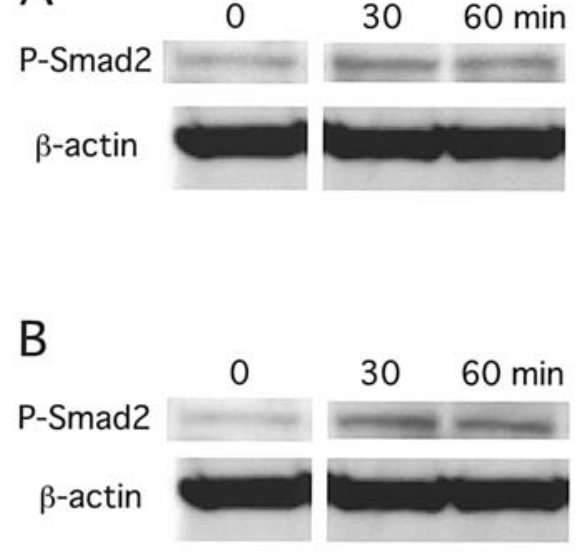

C

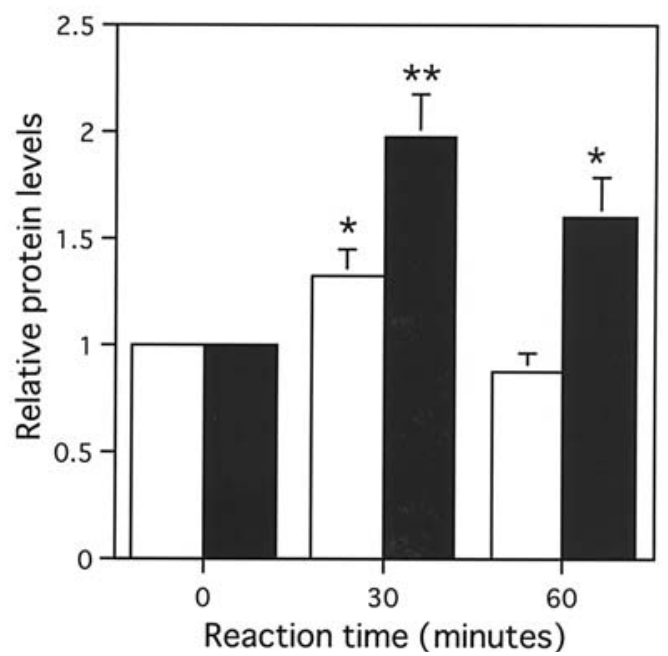

Figure 5. Smad2 phosphorylation in response to activin A in JHOC-5 cells. (A and B) Western blot indicating phosphorylated Smad2. Cells were treated with $10 \mathrm{ng} / \mathrm{ml}$ (A) and $30 \mathrm{ng} / \mathrm{ml}$ (B) activin A for 0,30 and $60 \mathrm{~min}$. The $\beta$-actin levels are shown in the bottom panels. (C) The histogram indicates the mean fold increase in phosphorylated Smad2 in response to $10 \mathrm{ng} / \mathrm{ml}$ (white column) and $30 \mathrm{ng} / \mathrm{ml}$ (black column) activin A, compared with that in untreated cells. Signals were normalized to the $\beta$-actin levels. Each value represents the mean \pm standard error, respectively. ${ }^{*} \mathrm{p}<0.05$ and ${ }^{* *} \mathrm{p}<0.01$ versus the control group by ANOVA $(n=3)$. 
with ovarian clear cell adenocarcinoma was $1.273 \mathrm{ng} / \mathrm{ml}$. Menon et al reported that the mean level of serum activin A of 27 postmenopausal patients with epithelial ovarian cancer was $1.130 \mathrm{ng} / \mathrm{ml}$ and that of 54 postmenopausal control was $0.690 \mathrm{ng} / \mathrm{ml}$ and that there was a statistically significant difference between the groups (25). According to this, it seems appropriate to judge that the activin A level in the serum 1 (Fig. 1A) of patients with ovarian clear cell adenocarcinoma was elevated compared with the healthy population. Our present data show that ovarian clear cell adenocarcinoma cells produce activin A, not inhibin A.

We previously reported that sex cord stromal tumors might produce inhibin A and inhibin B (19). We have reported that inhibin/activin subunits were localized in human ovarian serous and mucinous tumors and that overproduction of activins might promote cell proliferation in ovarian serous and mucinous adenocarcinomas (20). Welt et al reported that activin A was secreted in cultured human epithelial ovarian cancer (26). McPherson et al reported that prostate cancer cells produced activin A in the culture medium (27). It was reported that $72 \%$ of the stage III or IV patients with epithelial ovarian cancer had elevated activin A levels in preoperative serum compared with the control and that activin A levels dropped postoperatively and remained at or below the control level in patients in remission (28).

We demonstrated the expression of activin receptor type IA, IB, IIA, IIB, Smad2, Smad3, and Smad4 in JHOC-5 cells using flow cytometry and Western blotting. These results showed that activin signaling pathway existed in ovarian clear cell adenocarcinoma cells. Ito et al (29), using cultured ovarian cancer cell lines, reported that ovarian adenocarcinoma cells expressed mRNA of activin receptor type IA, type IIA, type IIB, Smad 2 and Smad4. Fuller at al (30) reported the mRNA expression of activin receptor type IA, IB, IIA, IIB in mucinous and serous cystadenocarcinoma. They also demonstrated that activin receptor type IA, type IB and type IIA exhibited wide spread albeit variable expression across tissues with the highest levels in serous tumor, whereas activin receptor type IIB expression was relatively low in the mucinous tumors (30). In addition, Dunfield et al (31) detected the expression of mRNAs of Smad2, Smad3 and Smad4 in ovarian epithelial cancer cell lines.

The present study revealed that activin A induced a significant increase in proliferation of JHOC-5 cells compared with the untreated control, whereas this stimulatory effect of activin A was completely inhibited by the treatment of follistatin, a specific binding protein of activin. These results indicate that activin may induce proliferation of ovarian clear cell adenocarcinoma.

Several investigators reported the effect of activin on proliferation of various kinds of cancers. Matzuk et al (32) demonstrated that inhibin could act as a novel secreted tumor suppressor protein with specificity for gonadal sex cord stromal tumors by their inhibin deficiency animal study. In addition, Shikone et al (33) demonstrated that activin A could act as an autocrine growth factor that stimulates the proliferation of cell lines derived from the gonadal sctromal tumors of inhibin $\alpha$-subunit knockout mice. Di Simone et al found that activin A induced cell proliferation in human ovarian cancer cell lines (34). Choi et al reported that activin A stimulated the growth of ovarian adenocarcinoma cells at concentrations of 1,10 , $100 \mathrm{ng} / \mathrm{ml}$ and that treatment with follistatin attenuated the stimulatory effect of activin (35). Steller et al found that activin A increased the cell proliferation, whereas inhibin A decreased it, in the presence of betaglycan using cultured ovarian cancer cell lines which include clear cell adenocarcinoma (36).

On the other hand, other investigators recognized activin to be a growth suppressor of various kinds of tumors. In hepatoma cell line, activin induced accumulation of retinoblastoma protein in hypophosphorylated form, reduced expression of cyclin-dependent kinase 4 and increased cyclin-dependent kinase inhibitor (CDKI), p2 $1^{\mathrm{WAF} 1 / \mathrm{Cip} 1}$ to suppress cell proliferation (37). Activin significantly inhibited the proliferation of hepatoma cells and increased gene expression of the CDKI, p15 INK4B $(38)$. In cultured pituitary adenoma cells, activin significantly inhibited cell proliferation (39). Activin A inhibited breast cancer cellular proliferation (40).

This study showed that phosphorylated Smad2 was expressed both in treated cells and in untreated cells by activin A, and activin A significantly increased the expression of phosphorylated Smad2. The data suggest that activin accelerates activation of its signaling pathway to induce cell proliferation in ovarian clear cell adenocarcinoma. Burdette et al reported that activin A increased the expression of phosphorylated Smad2 and phosphorylated Smad3 in breast cancer cells (40).

In summary, we observed that ovarian clear cell adenocarcinoma cells produced activin A, not inhibin A, and that they expressed activin receptor type IA, IB, IIA, IIB, Smad2, Smad3, and Smad4. Moreover, our data showed that activin A accelerated phosphorylation of Smad2 to induce proliferation in ovarian clear cell adenocarcinoma cells. Therefore, it is possible that activin has autocrine roles in the tumor growth of ovarian clear cell adenocarcinoma.

\section{Acknowledgements}

We thank Dr Y. Eto (Central Research Laboratories, Ajinomoto Co., Inc., Kawasaki, Japan) for kindly donating the recombinant human activin A and follistatin.

\section{References}

1. Sugiyama T, Kamura T, Kigawa J, et al: Clinical characteristics of clear cell carcinoma of the ovary: distinct histologic type with poor prognosis and resistance to platinum-based chemotherapy. Cancer 88: 2584-2589, 2000.

2. Tammela J, Geisler JP, Eskew PN and Geisler HE: Clear cell carcinoma of the ovary: poor prognosis compared to serous carcinoma. Eur J Gynaecol Oncol 19: 438-440, 1998.

3. Itamochi H, Kigawa J, Akeshima R, et al: Mechanisms of cisplatin resistance in clear cell carcinoma of the ovary. Oncology 62: 349-353, 2002.

4. Massague J: Transforming growth factor beta family. Annu Rev Cell Biol 6: 597-641, 1990.

5. Mason AJ, Hayflick JS, Ling N, et al: Complementary DNA sequences of ovarian follicular fluid inhibin show precursor structure and homology with transforming growth factor- $\beta$. Nature 318: 659-663, 1985

6. Lapolt PS and Hsueh AJW: Moleculer basis of inhibin production and action. Mol Cell Neurosci 2: 449-463, 1991.

7. Vale W, Rivier C, Hsueh AJW, et al: Chemical and biological characterization of the inhibin family of protein hormones. Recent Prog Horm Res 44: 1-34, 1988. 
8. Nakao A, Imamura T, Souchelnytskyi S, et al: TGF- $\beta$ receptormediated signaling through Smad2, Smad3, and Smad4. EMBO J 16: 5353-5362, 1997.

9. Whitman M: Smads and early developmental signaling by the TGF-ß superfamily. Genes Dev 12: 2445-2462, 1998.

10. Yue $J$ and Mulder KM: Requirement of RAS/MAPK pathway activation by transforming growth factor- $\beta 1$ production in a Smad-dependent pathway. J Biol Chem 275: 30765-30773, 2000.

11. Yue $J$ and Mulder KM: Transforming growth factor- $\beta$ signal transduction in epithelial cells. Pharmacol Ther 91: 1-34, 2001.

12. Woodruff TK and Mather JP: Inhibin, activin and the female reproductive axis. Annu Rev Physiol 57: 219-244, 1995.

13. Risbridger GP, Schmitt JF and Robertson DM: Activin and inhibins in endocrine and other tumors. Endocr Rev 22: 836-858, 2001.

14. Attisano L and Tuen Lee-Hoeflich S: The Smads. Genome Biol 2: 3010.1-3010.8, 2001.

15. Shi Y, Hata A, Lo RS, Massague J and Pavletich NP: A structural basis for mutational inactivation of the tumour suppressor Smad4. Nature 388: 87-93, 1997.

16. Massague J: TGF- $\beta$ signal transduction. Annu Rev Biochem 67: 753-791, 1998.

17. Pangas SA and Woodruff TK: Activin signal transduction pathways. Trends Endocrinol Metab 11: 309-314, 2000.

18. Lewis KA, Gray PC, Blount AL, et al: Betaglycan binds inhibin and can mediate functional antagonism of activin signaling. Nature 404: 411-414, 2000.

19. Yamashita K, Yamoto M, Shikone T, et al: Production of inhibin $\mathrm{A}$ and inhibin B in human ovarian sex cord stromal tumors. Am J Obstet Gynecol 177: 1450-1457, 1997.

20. Yamashita K, Yamoto M, Shikone T, Minami S and Nakano R: Immunohistochemical localization of inhibin and activin subunits in human epithelial ovarian tumors. Am J Obstet Gynecol 180: 316-322, 1999.

21. Mabuchi Y, Yamoto M, Minami S and Umesaki N: Immunohistochemical localization of inhibin and activin subunits, activin receptors, and Smads in ovarian clear cell adenocarcinoma. Oncol Rep 15: 291-296, 2006.

22. Yamada K, Tachibana T, Hashimoto H, et al: Establishment and characterization of cell lines derived from serous adenocarcinoma (JHOS-2) and clear cell adenocarcinoma (JHOC-5, JHOC-6) of human ovary. Hum Cell 12: 131-138, 1999.

23. Muttukrishna S, Fowler PA, Geoge L, Groome NP and Knight PG: Changes in peripheral serum levels of total activin A during the human menstrual cycle and pregnancy. J Clin Endocrinol Metab 81: 3328-3334, 1996.

24. Groome NP, Illingworth PJ, O'Brien M, et al: Detection of dimeric inhibin throughout the human menstrual cycle by twosite enzyme immunoassay. Clin Endocrinol 40: 717-723, 1994.

25. Menon U, Riley SC, Thomas J, et al: Serum inhibin, activin and follistatin in postmenopausal women with epithelial ovarian carcinoma. Br J Obstet Gynaecol 107: 1069-1074, 2000.

26. Welt CK, Lambert-Messerlian G, Zheng W, Crowley WF and Schneyer AL: Presence of activin, inhibin, and follistatin in epithelial ovarian carcinoma. J Clin Endocrinol Metab 82: 3720-3727, 1997.
27. McPherson SJ, Mellor SL, Wang H, Evans LW, Groome NP and Risbridger GP: Expression of activin A and follistatin core proteins by human prostate tumor cell lines. Endocrinology 140: 5303-5309, 1999 .

28. Lambert-Messerlian GM, Depasquale SE, Maybruck WM, Steinhoff MM and Gajewski WH: Secretion of activin A in recurrent epithelial ovarian carcinoma. Gynecol Oncol 74: 93-97, 1999.

29. Ito I, Minegishi T, Fukuda J, Shinozaki H, Auersperg N and Leung PCK: Presence of activin signal transduction in normal ovarian cells and epithelial ovarian carcinoma. Br J Cancer 82: 1415-1420, 2000

30. Fuller PJ, Zumpe ET, Chu S, Mamers P and Burger HG: Inhibinactivin receptor subunit gene expression in ovarian tumors. $\mathrm{J}$ Clin Endocrinol Metab 87: 1395-1401, 2002.

31. Dunfield LD, Dwyer EJC and Nachtigal MW: TGF- $\beta$ induced Smad signaling remains intact in primary human ovarian cancer cells. Endocrinology 143: 1174-1181, 2002.

32. Matzuk MM, Finegold MJ, Su JG, Hsueh AJ and Bradley A: Alpha-inhibin is a tumour-suppressor gene with gonadal specificity in mice. Nature 360: 313-319, 1992.

33. Shikone T, Matzuk M, Perlas E, et al: Characterization of gonadal sex cord-stromal tumor cell lines from inhibin-alpha and p-53 deficient mice: the role of activin as an autocrine growth factor. Mol Endocrinol 8: 983-985, 1994.

34. Di Simone N, Crowley WF, Wang QF, Sluss PM and Schneyer AL: Characterization of inhibin/activin subunit, follistatin, and activin type II receptors in human ovarian cancer cell lines: a potential role in autocrine growth regulation. Endocrinology 137: 486-494, 1996.

35. Choi KC, Kang SK, Nathwani PS, Cheng KW, Auersperg N and Leung PCK: Differential expression of activin/inhibin subunit and activin receptor mRNAs in normal and neoplastic ovarian surface epithelium (OSE). Mol Cell Endocrinol 174: 99-110, 2001.

36. Steller MD, Shaw TJ, Vanderhyden BC and Ethier JF: Inhibin resistance is associated with aggressive tumorigenicity of ovarian cancer cells. Mol Cancer Res 3: 50-61, 2005.

37. Zauberman A, Oren M and Zipori D: Involvement of p21WAF1/ $\mathrm{Cip} 1, \mathrm{CDK} 4$ and $\mathrm{Rb}$ in activin A mediated signaling leading to hepatoma cell growth inhibition. Oncogene 15: 1705-1711, 1997.

38. Ho J, De Guise C, Kim C, Lemay S, Wang XF and Lebrun JJ: Activin induces hepatocyte cell growth arrest through induction of the cyclin-dependent kinase inhibitor p15INK4B and Sp1. Cell Signal 16: 693-701, 2004.

39. Danila DC, Inder WJ, Zhang X, et al: Activin effects on neoplastic proliferation of human pituitary tumors. J Clin Endocrinol Metab 85: 1009-1015, 2000.

40. Burdette JE, Jeruss JS, Kurkley SJ, Lee EJ and Woodruff TK: Activin A mediates growth inhibition and cell cycle arrest through Smads in human breast cancer cells. Cancer Res 65: 7968-7975, 2005. 